\title{
Investigation of the Current Situation and Prospects for the Development of Rainwater Harvesting as a Tool to Confront Water Scarcity Worldwide
}

\author{
Stavros Yannopoulos ${ }^{1, *}$, Ioanna Giannopoulou ${ }^{2}$ and Mina Kaiafa-Saropoulou ${ }^{3}$ \\ 1 Faculty of Engineering, School of Rural and Surveying Engineering, Aristotle University of Thessaloniki, \\ GR-54124 Thessaloniki, Greece \\ 2 Alamanas 29A, Kalamaria, GR-55132 Thessaloniki, Greece; igiannop@gmail.com \\ 3 School of Architecture, Aristotle University, GR-54124 Thessaloniki, Greece; minakasar@gmail.com \\ * Correspondence: giann@vergina.eng.auth.gr; Tel.: +30-2310-996-114
}

Received: 15 September 2019; Accepted: 15 October 2019; Published: 18 October 2019

\begin{abstract}
Nowadays, available water resources face severe pressures due to demographic, economic, social causes, environmental degradation, climate change, and technological changes on a global scale. It is well known that rainwater harvesting, a simple and old method, has the potential to supplement surface and groundwater resources in areas that have inadequate water supply. In recent decades, many countries have supported the updated implementation of such a practice to confront the water demand increase and to reduce the frequency, peak, and volume of urban runoff. These considerations motivate interest in examining the current situation and the prospect of further development of this method worldwide. The present paper aims at the investigation of the current situation of rainwater harvesting (RWH) as an alternative water source to confront water scarcity in various countries around the world. In particular, the paper presents the following: (a) the causes of water shortage; (b) a concise historical overview of the temporal development of the RWH method; (c) the evolution of the concept of RWH; (d) the efforts to renew interest in RWH; and (e) incentives and perspectives for the spreading of the RWH method in various countries worldwide.
\end{abstract}

Keywords: water scarcity; alternative water source; rainwater harvesting; arid and semi-arid areas

\section{Introduction}

Water is a critical natural resource that plays an important role in the health, social, and economic development of a country, food production, and environment. Moreover, water is closely linked to fundamental human rights such as the right to life, to food, and to health and, consequently, access to safe water is a basic human right.

Globally, water availability has decreased more and more. Beyond the lack of rainfall and its erratic pattern in spatial and temporal scales, in many areas of the globe, available water resources face severe pressures due to demographic, economic, and social causes; environmental degradation; the impacts of climate change; and technological changes. Moreover, water demand is expected to increase in all sectors of production [1], while, by 2030, the world is projected to face a $40 \%$ global water deficit under the BAU (business as usual) climate scenario [2].

By 2025, water withdrawals are predicted to increase by $50 \%$ in developing countries and $18 \%$ in developed countries [3], while nearly 1.8 billion people will be living in areas under severe water stress, and the meeting of water requirements for different uses (agriculture, industry, domestic purposes, energy, and the environment, among others) will be on the threshold [4]. Furthermore, sources of pollution (non-point and diffuse) threaten the existing water resources, and they contribute to the degradation of the water quality of inland and coastal aquatic ecosystems. 
The Organisation for Economic Co-operation and Development (OECD) recommends, to its members, research on alternative sources in terms of water supply and, specifically, it suggested rainwater harvesting $(\mathrm{RWH})$, as well as grey and reclaimed water, as alternative water sources [5].

Regarding the physical alternatives to realize the sustainable management of freshwater, there are two solutions. The first one is to find alternative or additional water resources by using conventional centralized systems, while the second is the limited use of available water resources in a more efficient way. Until today, much attention has paid to the first case. Owing to the difficulty of developing new freshwater resources, rainwater harvesting, as well as water reclamation and reuse, are important additional water resources. Moreover, the collection, protection, and re-use of rainwater represent a viable process that can significantly increase available water resources and reduce flood risks. RWH is probably the most ancient practice in use in the world to confront water supply needs. Harvested rainwater is an alternative source of water in many parts around the world. In the last decades, many countries have supported a modern implementation of such a practice to address the increase in water demand pressures due to climatic, environmental, and societal changes. The overall aim of this paper is the investigation of the current situation on rainwater harvesting as a tool to confront water scarcity throughout the world, as well as prospects for spreading of the method.

\section{A brief Outline of the History of Rainwater Harvesting}

Archaeological findings in many parts of the world confirm that, since prehistory, people used to satisfy their domestic, irrigation, or livestock water needs by collecting and storing rainwater in simple cavities either in a low permeability soil or in rock. With the passage of the centuries, throughout the antiquity, rainwater was the main source of water for potable and non-potable use, thus rainwater harvesting was extremely important for their survival.

RWH was practiced about 4500 years ago by the people of the city Ur in the region of Sumer (in modern-day Iraq) and later by the Nabateans and other people of the Middle East [6]. The same process must have been applied in China 6000 years ago [7]. Moreover, archaeological evidence in southern Jordan indicates the existence of water collection systems, even 9000 years ago, for agricultural purposes, while similar water collection systems in the Negev desert of Israel were probably constructed about 4000 years ago (ca. 2000 BC), or even further back [8]. The collection and storage of rainwater in earthen tanks for domestic and agricultural uses has also been very common in India since the third millennium BC. In China, the history of RWH dates back 4000 years. Some of the early techniques that were used in the country included cisterns, roof open spaces, soil or rock pits, ditches, and micro-dams, among others [9]. Moreover, several archaeological findings suggest that RWH was common in many areas of the world, including Egypt, Thailand, Mexico, Pakistan, Ethiopia, Jordan, Korea, Sardinia, and so on. American Indians used similar systems 700 to 900 years ago in the southwestern United States [10]. Also, RWH has been practiced in rural Thailand for more than 4000 years [11].

Specific hydraulic structures for the harvesting and storage of rainwater were implemented in prehistoric times (ca. 3200-1100 BC) in different Minoan villages, cities, and palaces of Phaistos, Chamaizi, Myrtos-Pyrgos, Archanes, and Zarkos [12]. In addition, the Mycenaeans (1600 BC and ca. 1100 BC) built cisterns and several dams in the Peloponnese and Beotia that were essentially long, low dikes [13].

The cistern construction technology of the Minoans and Mycenaeans was improved by the ancient Greeks during the Archaic (c. 800-479 BC), Classical (478-323 BC), Hellenistic (323-30 BC), and Roman (30 BC-330 AD) periods.

In several Greek cities, rainwater was harvested through open spaces on the roofs, yards, and other open spaces into covered cisterns for storage and future use, in order to meet their daily water needs [14]. Numerous cisterns of the Classical and Hellenistic era have been found in private or public buildings all over Greece, and are quadrilateral or circular, for example, Delos, Akanthus, Santorini, Amorgos, Aiani (Kozani), and Pella. Bottle-shaped cisterns, with a narrow mouth, were quite common during the classical era in Athens, Piraeus, and Olynthus, and were still preferable during the Hellenistic 
period $[15,16]$. They were usually flat, pitched or vaulted roof, always coated with impervious material, and either built at ground level or carved deep into the earth, so as the harvested water could be kept cooler and thus more palatable, with its temperature constant. Many of them were multi-sectioned for water filtration. Their dimensions depended on their private or public use and the needs that had to be covered.

Afterwards, Roman private and public buildings included cisterns, very much similar to those in Minoan palaces or in Classical/Hellenistic constructions. They were usually located under paved courtyards, in order to collect rainwater and increase the water available from the city's aqueducts. Moreover, Roman rich houses and villas used to have shallow, oblong uncovered tanks, located on the ground, in the middle of the atrium, called an impluvium, in which rainwater was gathered from the ceiling, and particularly from a rectangular hole in the roof, known as a compluvium, so as to be available for household use or even for irrigating small gardens. Besides their decorative function, impluvia, especially in the early Roman era, were connected with underground storage cisterns, which is why they must be concerned as rainwater harvesting systems [16]. The majority of houses in Pompeii and Herculaneum possessed such hydraulic installations, while similar examples existed all over Greece, and in the eastern territories of the Roman Empire, as well as in North African cities [14].

\section{Revival of Interest for Rainwater Harvesting}

Rainwater Harvesting is both a simple and ancient method, which has been used for millennia in drier lands of the world, and particularly in regions where other water resources are scarce or difficult to access. It can vary from being small and basic, such as the attachment of a water butt to a rainwater downspout, to being large and complex, such as those that collect water from many hectares and serve large numbers of people [17]. However, the application of this method was reduced or even almost abandoned because of the following factors: (a) the available technical means during the industrial era, which made the water transfer from remote areas possible, through long and complex systems; (b) the ability to withdraw water from deep aquifers, so as to ensure the supply of large quantities of water for industry and urban water demands; and (c) the ability of the management of large quantities of water and supply, constantly and safely, via organized networks.

As Reddy [18] pointed out, the practice of RWH was then essentially abandoned until the early 1930s, except for collecting rainfall from rooftops in some areas. During the 20th century, and specifically before 1950, very few activities had taken place on the research and implementation of water collection techniques. In particular, farmers in Australia had already begun collecting water for domestic use and livestock after World War I. During World War II, there had been some water harvesting activities on islands with high rainfall, such as in Antiqua [19]. However, despite the fact that the revival of water harvesting techniques began in the early 1930s, the greatest activity in both construction and research began in the late 1950s [18]. Boers [20] noted that modern water-harvesting research started in the 1950s by H. J. Geddes, Professor of the University of Sydney in Australia.

According to Food and Agriculture Organisation (FAO) [21], renewed interest in the technology of water harvesting occurred in the 1950s in Australia, where "roaded catchments" based on the concept of compacted earth were constructed over more than 2000 hectares in order to collect water for agricultural purposes. These catchments were called "roaded catchments" because the soil was graded into a series of parallel roadways or gently sloping ridges that drained into the ditches separating them. These ditches carried the collected water to a storage reservoir by way of a collection ditch, which ran perpendicular to the roadways [18].

Prinz and Malik [19] pointed out that interest in water harvesting, both in the research and application level, was renewed partly because of the successful reconstruction of the water collection system for irrigation (1958 and 1959) by Evenari and his colleagues in the Negev desert of Israel. Pacey and Cullis [22] consider that the work of Evenari and his colleagues was of great significance because of the runoff farming models applied, the completeness of the research they conducted, and the historical sources of the models they used. 
In the USA, water harvesting begun during the 1940s and was generalized in the early 1950s, when several small catchments were built from small sheets of steel and concrete to provide drinking water to animals and wildlife. In the 1950s, Lauritzen had pioneered an innovative technique of constructing catchments and reservoirs that required the evaluation and use of plastic and artificial rubber membranes [18].

In 1955, an important movement in research interest took place, when cooperative studies on the collection of water for the livestock between the U.S. Department of Agriculture and the Utah Agricultural Experiment Station started by using the soil itself as a catchment surface and by treating it with waterproofing and stabilizing materials. In these studies, various soil cover materials were evaluated, such as plastic vinyl films, polyethylene-butyl rubber sheets, chemical sealants, and so on [23]. Of these materials, plastic butyl films, when not under tension, exhibited excellent wear resistance from exposure to solar radiation, and their installation was relatively simple. However, many of these high cost structures, which were used only by public authorities on public lands, failed within 5-10 years mainly as a result of strong winds, which caused extensive damages. In the 1960s, systematic studies were initiated by various organizations (governmental, private, and universities) in the USA, as well as in other arid or semi-arid countries, that concerned both the development and the assessment of new methods and materials to be used for the construction of water collection systems at low installation costs and the improvement of system reliability [24].

Further incentives for investigating the possibilities of water collection to improve plant production were provided owing to the widespread droughts that occurred in the 1970s and 1980s in Africa and their effects on crops. Much of the experience with rainwater harvesting was gained in Israel, USA, and Australia. However, this experience has limited relevance to resource-poor areas in the semi-arid regions of Africa and Asia [25].

Moreover, interest in collecting and storing water for irrigation purposes was enhanced because of the improvements of the Earthmoving machinery and sealing soil materials, which reduced the cost and difficulty of preparing catchment for collecting water, and improved the efficiency of the collection system. In general, since the 1950s, a series of experiments has developed the variety and sophistication of water harvesting technology.

In recent years, researchers and policy-makers have shown a renewed interest in water use strategies owing to rising water demand, an increased interest in conservation of water and energy, and an increased regulatory emphasis on reducing stormwater runoff volumes and associated pollutant loads [26]. In addition, many countries have renewed their attention in water collection techniques, which are regarded as a viable decentralized water source. The renewal of interest is also related to the role that decentralized water collection systems can play to mitigate flood risks, among others, and because the decentralized multi-purpose rainwater harvesting systems constitute useful infrastructures to mitigate other water-related disasters, such as sudden water break and fire events, especially in highly developed urban areas. Nowadays, the art of collecting rainwater has received renewed attention and interest in many countries as a viable decentralized water source globally, like Germany, Italy, Spain, and France, among others, in Europe; India, China, Malaysia, Japan, and South Korea, among others, in Asia; Kenya, Ethiopia, and Syria, among others, in Africa; in several states of the USA (Nevada, Utah, and so on) and Canada; Brazil in South America; and Australia and New Zealand [14].

\section{Rainwater Harvesting: Origin, Terminology, Concept}

Koenig and Sperfeld [27] pointed out that the English term "rainwater harvesting" (RWH) is widely accepted internationally. However, there is not a unified definition about this term that is commonly accepted by the scientific community [14]. Researchers employ a wide variety of terms and definitions to describe the various methods aimed at the use of, collection, and storage of rain runoff in order to increase the availability of water for drinking, irrigation, and so on in arid and semi-arid areas [28]. In this way, their criterion is their own purposes and not a strict definition of the term "rainwater harvesting". 
The harvesting of rainwater can be either directly from the atmosphere or via runoff. In the first case, rainwater quality is influenced by the atmospheric conditions, while in the second case, the quality is a major matter of concern and quality parameters as $\mathrm{pH}, \mathrm{COD}, \mathrm{BOD}_{5}, \mathrm{SS}$, nitrates, and so on are considered.

According to Pacey and Cullis [22], the term "rainwater harvesting" derives from the more general term "water harvesting". In the general sense, the term "water harvesting" describes a range of techniques for the collection and concentration of runoff. Usually, water harvesting is used as a generic term encompassing a whole range of methods for the collection and concentration of various forms of runoff (overland flow, rooftop runoff, ephemeral streams, and so on) from various sources (rain or dew) and for various purposes (agricultural, livestock, domestic water supply, environmental management) [14].

The origin of the term "water harvesting" is not well known. Probably, Professor H.J. Geddes of the Sydney University, Australia, is the first who used the term "water harvesting". He defined water harvesting as "the collection and storage of any farm of waters either runoff or creek flow, for irrigation use" [29]. In this definition, water harvesting includes stream flow in creeks and gullies, not just rainwater at the point where it falls [22]. Later, Currier [30] defined water harvesting as "the process of collecting natural precipitation from prepared watersheds for beneficial use".

In 1974, Geddes stated "The phrase 'water harvesting' was coined in the first instance to describe a project of the University of Sydney, which involved the collection and economic storage of farm runoff for irrigation, and to differentiate the work from normal farm water conservation to provide water for livestock or household purposes" and also he pointed out, "the phrase water harvesting has been adopted by others and given a wider connotation" [31]. Myers [10] generalized the definition of water harvesting as "the practice of collecting water from an area treated to increase runoff from rainfall and snowmelt".

In the past, a variety of expressions have been used in order to identify water harvesting techniques. The important basic factors in the various definitions of water harvesting are the surface runoff, the source of runoff, the form of runoff, and the harvesting techniques itself.

A brief review of the international literature shows that, in some definitions, the source of runoff is the key factor, such as "rainwater harvesting" [22,32], "rain harvesting" [33], "rainwater collection" [22,33], and "rainfall collection" [33]. Some definitions include dew and/or dew and mist and/or snow as a water source. However, the amounts of water that can be harvested from these sources are very small and of no particular interest.

In some cases, the term "water harvesting" includes only the surface runoff from the slopes and runoff from ephemeral streams. For example, Boers and Ben-Asher [32] are referred in "local surface runoff", MoALD [34] in "sheet runoff or ephemeral stream flows", Critchley [35] in "runoff before it reaches seasonal or permanent streams", Bruins et al. [36] in "runoff from whatever type of catchment or ephemeral stream", and Pacey and Cullis [22] in "water running off surfaces on which rain has directly fallen". In addition, there are definitions of "water harvesting" based on "stream flow", such as "harvesting stream flow" [37], "floodwater farming" [33], and "floodwater harvesting" [22,35].

Several specific terms have been used for the definition of "water harvesting" for agricultural purposes, such as "runoff agriculture" [38], "runoff farming" [10,22,39], "runoff culture" [40], "agricultural water harvesting" [39], and "floodwater farming" [33]. Bruins et al. [36] used the terms "runoff farming", "runoff agriculture", and "rainwater harvesting agriculture" alternatively to describe "farming in dry regions by means of the flow of rainwater from whatever type of catchment or ephemeral stream".

It is mentioned, however, that Bruins et al. [36] noticed that the term "water harvesting" is a purely hydrological sense, and it does not determine what kind of water is harvested nor the purposes for which the water will be used.

It is not the purpose of this paper to encompass an exhausting commentary on the semantics of the term "rainwater harvesting" and, consequently, this topic is not covered completely. In the 
framework of the present study, rainwater harvesting means the method by which rainfall that falls upon a surface catchment area (roof, sidewalks, parking lots, landscape areas, and so on) is collected and routed to a storage facility for direct or future use (domestic and agricultural use). It is indicated that RWH does not reduce the demand, but it can reduce the water abstraction needs. In the past, the rainwater harvesting practice was used in arid or semi-arid areas, while in the modern day, the use of rainwater harvesting also extended to sub-humid and humid regions.

\section{Examples and Utilization of RWH Around the World}

As aforementioned, in recent decades, the interest in rainwater harvesting for both developing and developed countries (including several EU Member States) is growing. The success of RWH systems depends to a great degree on their technical design and the identification of suitable sites, as the appropriate sites for the various RWH technologies in large areas represent a great challenge. For this reason, many researchers have developed and applied various methodologies and criteria to identify suitable sites and techniques for rainwater harvesting. The development in computer technology, hydrological modeling, multi-criteria analysis, geographical information systems (GIS), and remote sensing has made it possible to develop new procedures to identify suitable sites for RWH. In addition, researches and applications have been carried out at various levels on the following: (a) the use and management of RWH; (b) the quality of harvested rainwater; and (c) hydrological or economic data for RWH.

However, the degree of its modern implementation varies greatly across the world, frequently with systems that probably do not maximize potential benefits.

In several countries, both governments and local/regional authorities have promoted measures to install and use RWH systems, mostly under a legal framework, with financial incentives (subsidies, reductions or tax refunds, and so on). For example, some form of RWH is mandatory for buildings and houses in various cities and states of India (New Delhi, Indore, Chennai, Rajastan, and so on); in Catalonia of Spain; in Flanders of Belgium; in new buildings of some states of the USA (Tucson, Arizona, New Mexico, and so on); in many Caribbean islands; in Germany (Hessen, Baden-Württemberg, Saarland, Bremen, Thuringen, Hamburg, and so on); for newly constructed buildings in Seoul of South Korea; and in Malaysia only for large buildings like factories, schools, or bungalows, among others. The same is true in some Australian states, such as South Australia, New South Wales, and Queensland, where regulations stipulate a new rainwater collection system or alternative water source.

Meanwhile, manuals were developed about the design, construction, and management of rainwater harvesting systems, for example, in the United Kingdom, Malaysia, Japan, India, and Canada, among others. In the USA, the federal government does not regulate rainwater harvesting, but rather it is up to individual states to regulate the collection and use of rainwater. Some states, including Georgia, North Carolina, and Texas, among others, have published manuals that provide information on the types of processing systems and components needed for meeting specific water quality objectives. In addition, at the municipal level, several major cities, such as Los Angeles, San Francisco, Tucson, and Portland, have issued guidelines and/or policy documents on treatment and permitting requirements for rainwater collection systems [26].

To the best of our knowledge, there are neither European nor national regulations on the definition of quality standards for rainwater uses within the European Union. In several countries of the European Union, such as France (Décret du 2 Juillet 2008) and the United Kingdom (BS 815, 2009), some standards have been proposed, which are merely guidelines (directives) focusing on domestic uses of rainwater. In Spain, there is the Royal Decree 1620/2007, which establishes quality standards for possible uses of recycled water [41]. However, there is a lot of interest in rainwater harvesting in many European countries, including Germany, France, Spain, Italy, Cyprus, Malta, United Kingdom, Austria, Belgium, Denmark, Portugal, and so on. 
RWH is not restricted to simple, small-scale roof collection systems, but is extended to the following: (a) larger systems usually used for providing water for schools, stadiums, airports, and so on; (b) collection systems for high-rise buildings in urbanized areas; and (c) land surface catchment systems and stormwater collection systems to prevent the pollution of water sources from roads, industrial sites, and agriculture. Large-scale RWH systems exist, as follows: (a) in Germany, such as in Berlin the Daimler Chrysler Potsdamer Platz and the building complex at Belss-Luedecke-Strasse; in Darmstadt, the Technical University; in Frankfurt, the Airport, among others; (b) in the United Kingdom, in London, the Millennium Dome, the Museum, and the Velodrome, among others; in Manchester, the Honda Dealership; in Bristol, the Imperial Tobacco Head; (c) in Singapore, the Changi Airport; (d) in Japan, in Sumida city, the Ryogoku Kokugikan Sumo-wrestling Arena and the Town Hall, among others; in Tokyo, the Rojison and the Sky Tower; and (e) in South Korea, in Seoul, the Star City Project in Kwangjin-Gu, among others.

In developed countries, including Japan, Singapore, Belgium, France, Germany, USA, Sweden, Canada, Spain, and so on, RWH is mostly used to supplement conventional systems for non-drinking water purposes such as irrigation, laundry, and toilet flushing, while in Australia, the collected water also has potable use. In developing countries, such as Bangladesh, Botswana, India, Kenya, Nepal, Namibia, Uganda, South Africa, and so on, RWH is mainly used to address water shortages for both potable (drinking, cooking, personnel hygiene, and so on) and non-potable purposes [42,43].

In several Latin American countries (Argentina, Brazil, Costa Rica, Chile, Mexico, and Peru), the RWH practice from roofs for domestic consumption is applied, while in the semi-arid areas of Argentina, Brazil, and Venezuela, runoff collection from roads with drainage ditches and street gutters is used, from which water is then transferred to cultivated areas for irrigation [44].

In Australian cities, RWH is popular. In urban areas, RWH systems are used to complement the main water system, whereas many rural and peri-urban communities completely rely on this. A total of $30 \%$ of rural Australians use RWH, while $7 \%$ use RWH in the capital cities. About $13 \%$ of all Australian households $\left(2.6 \times 10^{6}\right.$ people) use RWH systems as a primary source of drinking water [45]. Local authorities throughout Australia encourage the use of RWH systems in urban areas to supplement main water supplies and to manage urban stormwater runoff. For this reason, the Australian state and local governments adopted a wide range of policies, including subsidies and grants, to provide the installation of rainwater tanks in houses. These incentives vary from state to state, depending on the size of the water reservoir and the purpose of using the collected water. In South Australia, almost 50\% of the population live in houses equipped with a rainwater tank. RWH is mandatory for new homes in Queensland [46].

In the USA, rainwater harvesting has become an increasingly common practice. Since 2004, it has been estimated that about 100,000 residential RWH systems were in use in the USA and its territories [7]. Some states and territories (Hawaii, Kentucky, New Mexico, North Carolina, Ohio, Oregon, Texas, Utah, and Washington, among others) consider RWH as a serious practice for protecting water resources, as well as for increasing the available volume of water for potable use. However, even though the major use of harvested rainwater is for landscape watering, flushing toilets, and so on, there are a number of systems that serve indoor uses as well.

In Bermuda, rooftop RWH is compulsory by law for all buildings and constitutes the primary source of water for domestic supply. The Public Health Act regulates the details for the maintenance and conservation of the catchments, tanks, gutters, pipes, vents, and screens in order for them to be maintained in a good situation [47].

In Canada, most of RWH systems are for residential use in rural areas, where there is no access to central public water supply systems. In cities, most cases relate to buildings that have been certified according to one of the green building rating systems, in which the reuse of rainwater and the reduction of runoff were taken into account [48]. Since 2010, the National Plumbing Code has been in force, which permits the use of rainwater for toilet and urinal flushing, as well as subsurface irrigation. In addition, it permits the use of rainwater, both indoor and outdoor, depending on the level of 
treatment. RWH is mandatory for new homes in Queensland [46]. In Ontario, several municipalities recognize RWH as an important tool for confronting problems arising from the management of water resources. The City of Toronto and the Regional Municipality of Waterloo have been active in promoting the technology through stormwater and green building policies [49].

In Mexico, RWH makes a significant contribution to reducing the water supply shortage that occurs in large areas of the country. Specifically, the National Water Plan to increase the percentage of the population with easy access to drinking water and improve the efficiencies of water services in the municipalities has adopted RWH as an alternative water supply. In addition, the National Water Commission (CONAGUA) has developed the National Program for Rainwater Harvesting and Eco-techniques in Rural Areas in order to provide water to rural populations. RWH practice is applied in various states of the country, such as State of Mexico, Guanajuato, Querétaro, Michoacán, Morelos, Zacatecas, San Luis Potosi, and others. In rural areas of the country, RWH use predominates, while in urban areas, it is mainly used for sanitation, watering, and cleaning. The potable use is accepted in some primary schools [50].

In Brazil, there is no legislation to cover RWH at the federal level. Since 2007, NBR-15227 has been in force, which has normative character and regulates the use of rainwater for non-potable purposes in urban areas. However, there are various cities and municipalities that have enacted guidelines that regulate the catchment and storage of rainwater for non-potable uses. Since 2002, the city of Sao Paulo has been pioneer as it implemented the first law regulating these aspects. Thence, other major cities including Rio de Janeiro, Curitiba, and Paraiba, among others, have implemented similar regulations. Owing to the large number of different laws and regulations in force in the different parts of the country, it is difficult to assess the extent to which Brazil is implementing RWH as an alternative to the municipal water supply systems [51].

In African countries, rainwater collection systems are being increasingly adopted. However, despite the rapid expansion of these systems, progress is slow because of the following factors: (a) the low rainfall and its seasonal nature, (b) the small number and size of impervious roofs, (c) the high cost of constructing catchment systems in relation to typical household incomes, (d) the lack of cement and pure graded sand in some parts of Africa, and (e) the lack of sufficient water for the construction industry, which burden the total cost. However, RWH systems are increasingly expanding in Africa with works in Botswana, Mali, Malawi, South Africa, Namibia, Zimbabwe, Tanzania, and so on [52].

The effort to develop rainwater collection systems in Africa is led by Kenya, which has a very long tradition in these systems through the centuries. Since the late 1970s, interest in RWH has rapidly grown. In different parts of the country, many RWH projects have been carried out, each one with their own designs and implementation strategies, in an effort to provide long-term solutions to water resource problems [52]. In the middle of the 20th century, the Government began to build rock catchment systems that served communities in the semi-arid area of Kitui district [47]. The variety of geographic and climatic conditions in the country has enabled the development of a very wide range of RWH technologies for water supply, agriculture, and livestock. In Nairobi, there are several manufacturers of water tanks from plastic, metal, and other materials. These tanks are sold everywhere in East Africa and beyond [47]. In many parts of Kenya, the United Nations Development Program and the World Bank consider rainwater storage tanks as an essential part of their program on water supply and sanitation [53]. It is noted that, although it is not mandatory for institutional buildings to dispose RWH facilities, many of them, especially in the rural areas, have those facilities. In 1994, the Kenya Rainwater Association was established, which is the first national RWH association in Africa. Since then, tens of thousands of rainwater collection systems have been built in Kenya by a wide range of organizations; as a result, millions of people are benefiting from these systems [47].

Japan is one of the developed countries in Asia that has a strong international exchange of experience in the use of RWH. Since the mid-1980s, Tokyo and other Japanese cities, as well as most municipalities and organizations of the country, have given particular importance to RWH so as to have safe water supplies to deal with emergencies, floods, rehabilitation of the natural hydrological 
cycle, and exploration of alternative water sources for non-potable use [54]. Moreover, the abnormal drought of 1994 and the Great Hanshin-Awaji Earthquake of 1995 highlighted the importance of securing water supplies from the viewpoint of disaster preparedness. A large number of municipalities re-evaluated the importance of RWH and tried to identify alternative water resources, as a means to prevent urban flooding and to secure emergency water for disaster responses. The issue was regulated by ordinance and guidelines according to the local conditions [55]. According to the survey of the Association for Rainwater Storage and Infiltration Technology held in April 2011, 208 municipalities are implementing subsidy programs for the establishment of facilities for storing or filtration systems of rainwater, and of these, 179 provide subsidies for installation of rainwater tanks. In April 2014, the Japanese Diet passed the Act to Advance the Utilization of Rainwater, which went into force in May 2015. Under this act, municipalities are obliged to make their best effort to define and work toward rainwater utilization targets, while the national government is required to grant financial support for subsidy programs. These arrangements are expected to provide a national mobilization to promote the technical rainwater use [56]. On 10 March 2015, the Japanese government, based on the above act, approved the wider usage of RWH systems in newly constructed buildings by the state government or incorporated administrative agencies, aiming for a 100\% installation rate [57]. In Japan, the placement of small-sized RWH facilities with a storage capacity less than $1 \mathrm{~m}^{3}$ is widespread in individual houses. It is noted that the Great Earthquake in Eastern Japan in March 2011 caused a sudden rise in the number of households that installed tanks to store rainwater for emergency [58]. In Japan, rainwater utilization is now flourishing at both the public and private levels [59]. There are approximately 2800 large-scale systems for water recycling or rainwater use in Japan [60].

In China, the growing interest in RWH was initiated in the 1980s owing to the widespread droughts of that decade, which was followed by serious shortages of drinking water and crop failures [61]. RWH practice and utilization are applied mainly in areas with the following types of water scarcity [53]: (a) in water deficient areas with a lack of water resources, such as Gansu and central Ningxia; (b) in areas with seasonal water deficit, such as Fujian, Guizhou, and other hilly areas; (c) in areas with water deficit, but also with difficulty in exploitation, such as the southwest mountainous areas of the country; (d) in water deficient areas with poor water quality, for example, brackish water, fluoride water, and high-arsenic water. In these areas, authorities have constructed water cellars, tanks, ponds, and other miniature water conservancy projects as an effective solution to the problem of water shortage. Unfortunately, there are still problems of water deficit. Seventeen provinces in the country have adopted the RWH practice by building 5,600,000 tanks with a total capacity of $1.8 \times 10^{9} \mathrm{~m}^{3}$, supplying water to about $15 \times 10^{6}$ people, and supplemental irrigation of $1.2 \times 10^{6}$ ha of land [47]. RWH systems are also applied in the provinces of northwestern China (Ningxia Region, Shanxi Shaanxi, and the Inner Mongolia Region), as well as in the southwest and southeast provinces of the country (Guangxi Region and Guizhou Province). The implementation of RWH has a significant impact on the development of China's semi-arid rural areas and has practically solved the drinking water problems of populations living in semi-arid mountainous areas of the country [61].

In India, RWH was revived in the 1960s in response to declining groundwater availability caused by the rapid expansion of irrigation pumping. Many Indian cities have insufficient water supplies to meet their needs. Urban development makes it both difficult and expensive to build dams, pipelines, and canals commonly used nowadays in order to supply water to cities. RWH supported agriculture for many years in India, while there is a demand in urban areas for novel methods for decentralized water supply systems. Since 2000, the legislation on RWH has been changed in the various states and federal regions of the country, and it is compulsory for new buildings. Rooftop RWH systems are mandatory for new buildings in 18 of the 28 states and 4 of the 7 federal regions of the country [62].

In Malaysia, the promotion of RWH use began in 1999 with the introduction of the Guidelines for "Installing a Rainwater Collection and Utilization System" by the Ministry of Housing and Local Government. In 2006, the Ministry of Energy, Water, and Communication introduced the Water Services Industry Act 2006 and the Water Services Commission Act 2006, under which the 
Ministry encouraged the citizens to implement RWH systems. In 2009, guidelines entitled "Rainwater Harvesting: Guidebook for Planning and Design" were introduced by the Department of Irrigation and Drainage (DID), followed by "Guideline on Eco-Efficiency in Water Infrastructure for Public Buildings in Malaysia" by the National Hydraulic Research Institute of Malaysia in 2011 and "Urban Stormwater Management Manual for Malaysia" (2nd Ed.) by the DID in 2012. In 2011, the Malaysian government imposed the installation of RWH systems in several cases of buildings, such as all types of buildings with a roof area equal or more than $100 \mathrm{~m}^{2}$ and residential buildings (bungalow and semi-detached) of the country. In addition, in 2013, the "Guidelines for Installing a Rainwater Collection and Utilization System" of 1999 were revised [63]. As Mohd.-Shawahid et al. [64] stated, the most encouraging development to make RWH mandatory in Malaysia was the two guidelines of 2006, although this policy was applied only to large buildings like factories, schools, or bungalows. In addition, they considered that it is certainly a step in the right direction to make RWH mandatory, despite the fact that there is still a lack of robust policy to promote the installation of RWH systems in Malaysia. According to Lee et al. [63], rainwater is collected for general washing and gardening purposes, but the common use of rainwater in a building is for toilet flushing, whereby the rainwater cistern is connected to the water closet fittings to minimize the use of treated water for non-potable use.

In 2009, the government of Taiwan introduced new water regulations, which included wastewater reuse, seawater desalination, and rainwater harvesting as alternative water resources for domestic water supply. In 2003, a green building policy was developed. This policy requires new buildings with a total floor area greater than $10,000 \mathrm{~m}^{2}$ to have installed domestic rainwater harvesting equipment to supply at least $5 \%$ of the total water required by the building [65].

Germany has developed new and sophisticated RWH systems and techniques and is considered as one of the leading countries in the world in this field. In particular, Germany has more than $1.5 \times 10^{6}$ integrated rainwater systems not only in homes for toilet use, but also for car washes and garden irrigation, as well as in service water demanding industries [66]. According to the Environmental Agency [48], 35\% of new buildings in the country are equipped with a RWH system, and from 50,000 [67] to 80,000 [68] of such new systems are installed every year. As Partzsch [68] pointed out, in 2005, every third new building in Germany was supplied with a rainwater storage tank. In Germany, the promotion of RWH in households has become widespread since the 1980s [67]. Schuetze [69] presented a documented description on rainwater harvesting and management in Germany.

In the United Kingdom, modern RWH systems have been introduced relatively recently [48], as the interest in RWH research, technology, development, and utilization has yet to mature, although several initiatives are in place to promote RWH [70]. The Code for Sustainable Homes, which is in force in England, Northern Ireland, and Wales, supports and encourages the promotion of installation of RWH systems in new houses. In particular, owners of new homes are encouraged to save money and water resources by installing RWH systems for toilets, washing clothes, garden watering, and car washing. According to UKRHA (United Kingdom Rainwater Harvesting Association) [71], approximately 100,000 RWH systems already exist in the United Kingdom and approximately 4000 systems per year are installed, which are commonly internally plumbed to supply toilet flushing as well as garden irrigation.

In France, the interest in RWH for indoor and outdoor uses has increased, and constitutes a serious issue even in urban areas. As Gerolin et al. [72] pointed out, "rainwater harvesting (RWH) has known a revival of interest since the establishment in 2006 of a national tax credit for households implementing a rainwater collection system“. Since 2008, a decree (French Government Order of 21 August 2008) concerning RWH has been in force. In reality, it is about regulations, which define better management of the use of rainwater and the precise technical requirements to be met by the components of the collection systems supplying both outdoor and indoor uses. Specifically, the regulations prohibit the use of harvested rainwater for drinking, showering, or bathing, but they allow its use for toilet flushing; cleaning the ground; and, under certain conditions, washing clothes [73]. In France, according to a survey conducted in 2009, $15 \%$ of the population have an RWH system in urban areas [74]. 
Belgium has national legislation that supports RWH, which stipulates that all new constructions must have a rainwater collection system, the water of which can be used for washing the toilet and for external water uses. In Flanders, it is estimated that $10 \%$ of current household water consumption comes from RWH, which could be increased to $25 \%$ by 2025 . It is estimated that households account for $72 \%$ of the total rainwater use in Flanders [75].

In Portugal, the ERSAR (Water and Waste Services Regulation) guidelines allow the use of RWH only for non-potable use and, in particular, for irrigation purposes. In 2012, ANQIP (National Association for the Quality of Building Installations), a nonprofit organization promoting water sustainability at the building level, published a technical document (ETA 0701, 2012) describing the procedures to be taken into account regarding the installation of rainwater collection systems in Portuguese buildings [76].

In Malta, a significant proportion of $35.4 \%$ of households are currently using RWH, of which $33.6 \%$ collect it in underground cisterns and a small percentage of $1.8 \%$ in plastic containers. Since 2004, the exploitation of RWH in new constructions has been regulated by the plan of the MEPA (Malta Environment and Planning Authority), which regulates the creation of water collecting surfaces on roofs, the possible size and capacity of the tanks, and so on [77].

\section{Conclusions}

Worldwide, many countries are facing water shortages more and more growing as a result of the continued increasing demand for water from various competing users like domestic, agriculture, industry, and environment use, as well as because of urbanization, climate change, water pollution, and so on. All of these factors exert pressures on the existing water resources. One of the biggest challenges of the 21st century is to overcome the growing water shortage.

In general, the flawed strategy was the construction of large-scale projects (dams, long-distance pipelines, pumping stations, and so on), as their construction has not proven sufficient to meet the water needs of the different users, while at the same time, they had significant social, economic, and environmental impacts, and required significant investment. Therefore, searching for alternative water sources (grey water, desalination, and RWH) has attracted worldwide interest. RWH is seen as a more promising alternative or supplementary water resource owing to its minimal environmental impact, the low treatment needs in comparison with other alternative water sources, the benefits from flood mitigation, and many other reasons.

RWH is a very old traditional and sustainable practice that has been adopted in many ancient sites as a water supply method for both potable and non-potable purposes. Nevertheless, RWH, which was a worldwide technology, has been neglected over the past 150 years because of new technologies, which enable us to store, pump from deep groundwater, and transport huge volumes of water (ground and surface) via dams, pump stations, and long length pipelines.

The literature reveals that the interest and use of RWH systems, on a global basis, has been continually increasing from about the beginning of the second half of the previous century onwards. There is a trend for the revival of traditional technologies, blending them with modern methods to meet the required needs of water, in the present and future. As Yannopoulos et al. [14] stated, "Worldwide, rainwater harvesting has retrieved its importance as a valuable water resource, alternative or supplementary, in conjunction with more conventional water supply technologies. If rainwater harvesting is practiced more widely, many water shortages, actual or potential, can be alleviated".

Nowadays, a large number of countries all over the world consider RWH as a viable decentralized water source and have started considering and practicing rainwater harvesting as a sustainable development strategy. However, a significant push to extend this technique is required. Specifically, significant efforts are still needed in research, investments, information, education of the public on the importance of rainwater harvesting, economic incentives (subsidies and tax exemptions), suitable legislation, and regulations.

Until today, two approaches have been applied concerning the extension of RWH, namely either voluntary via incentive-based programs or via mandated regulations. In several countries, government 
subsidies and rebate programs can be particularly effective in promoting RWH implementation. Contrary to regulations that require compliance, subsidies target individuals with an appreciation for RWH and provide an incentive for them to pursue adoption of this practice.

It is noted that the main variable of interest for the design of an RWH system in a particular locality is rainfall (intensity, frequency, and temporal variability). Therefore, the reliability of rainfall in terms of both spatial and temporal distribution constitutes a critical factor in the performance of an RWH system. Moreover, alteration of the rainfall pattern and its variability in the future is likely to take place as a result of climate change, which can introduce uncertainty in the design of RWH systems (tank storage). RWH systems have many benefits, for example, (a) they provide important economic advantages for consumers because they reduce the amount of water purchased from public systems; (b) they give the possibility of an alternative water supply and, consequently, reduce pressure on surface water sources and aquifers; (c) they are simple and inexpensive technologies that are easy to install, maintain, expand, reconfigure, or relocate to meet the needs of each household. In this way, RWH systems are an effective tool to minimize the use of treated water for non-potable uses and supply drinking water in places where the existing sources cannot meet the water needs; furthermore, they are an effective adaptive strategy to climate change against the reduction of water availability and for the control of runoff. In addition, RWH systems decrease (a) the flow of stormwater drains; (b) nonpoint source pollution; (c) onsite erosion and flooding; and (d) the costs of managing runoff.

Despite the aforementioned benefits, RWH systems cannot supply water for all domestic uses and it is almost impossible for them to make the households independent of conventional water supply systems. However, RWH systems can serve as the main water source in rural areas in which the availability of water resources is a critical issue; furthermore, they can constitute a complementary water supply in urbanized areas, provided that they will connect with existing conventional water supply systems.

Author Contributions: S.Y. had the original idea, supervised the research, prepared the manuscript, and mainly carried out the data collection; I.G. and M.K.-S. conducted the review of it, made English corrections, and contributed to manuscript preparation.

Funding: This research received no external funding.

Acknowledgments: Part of this paper was presented at the XIV International Conference Protection and Restoration of the Environment, 3-6 July 2018, Thessaloniki, Greece, and published in its Proceedings: (Theodosiou, N., Christodoulatos, C., Koutsospyros, A., Karpouzos, D., Mallios, Z., Eds.): Yannopoulos, S.; Giannopoulou, I.; Kaiafa-Saropoulou, M. Rainwater Harvesting as an Alternative Source to Confront Water Scarcity Worldwide-Current Situation and Perspectives, pp. 64-75.

Conflicts of Interest: The authors declare no conflict of interest.

\section{References}

1. WWAP (World Water Assessment Program). The United Nations World Water Development Report 4: Managing Water under Uncertainty and Risk; UNESCO: Paris, France, 2012; p. 391. ISBN 978-92-3-104235-5.

2. 2030 WRG (2030 Water Resources Group). Charting Our Water Future: Economic Frameworks to Inform Decision-Making; 2030 WRG: Washington, DC, USA, 2009; p. 185.

3. WWAP (World Water Assessment Program). The State of the Resource, World Water Development Report 2, Chapter 4; U.N. Educational, Scientific and Cultural Organization: Paris, France, 2006.

4. UN Water. Coping with Water Scarcity: Challenge of the Twenty-First Century. Prepared for World Water Day 2007. Available online: http://www.unwater.org/wwd07/downloads/documents/escarcity.pdf (accessed on 23 March 2007).

5. OECD (Organization for Economic Co-Operation and Development). Alternative Ways of Providing Water: Emerging Options and Their Policy Implications; Advance Copy for 5th World Water Forum; OECD: Paris, France, 2009; p. 33. Available online: https://www.oecd.org/env/resources/42349741.pdf (accessed on 10 March 2018). 
6. Sivanappan, R.K. Rain water harvesting, conservation and management strategies for urban and rural sectors. In Proceedings of the 22nd National Convention of Environmental Engineers and National Seminar on Rainwater Harvesting and Water Management, Nagpur, India, 11-12 November 2006; Institution of Engineers: Nagpur, India, 2006; pp. 1-5.

7. TWDB (Texas Water Development Board). The Texas Manual on Rainwater Harvesting, 3rd ed.; Texas Water Development Board: Austin, TX, USA, 2005.

8. Evenari, M.L.; Shanan, L.; Tadmor, N.; Aharoni, Y. Ancient agriculture in the Negev. Science 1961, 133, $979-996$. [CrossRef]

9. Akpinar-Ferrand, E.; Cecunjanin, F. Potential of rainwater harvesting in a thirsty world: A survey of ancient and traditional rainwater harvesting applications. Geogr. Compass 2014, 8, 395-413. [CrossRef]

10. Myers, L.E. Water harvesting 2000 BC to 1974 AD. In Proceedings of the Water Harvesting Symposium, Phoenix, AZ, USA, 26-28 March 1974; USDA, February 1975, ARS W-22. pp. 1-7.

11. Visvanathan, C.; Vigneswaran, S.; Kandasamy, J. Rainwater Collection and Storage in Thailand: Design, Practices and Operation. J. Water Sustain. 2015, 5, 129-139.

12. Angelakis, A.N. Evolution of rainwater harvesting and use in Crete, Hellas, through the millennia. Water Sci. Technol. Water Supply 2016, 16, 1624-1638. [CrossRef]

13. Mays, L.W. A Brief History of Water Technology during Antiquity: Before the Romans. In Ancient Water Technologies; Mays, L.W., Ed.; Springer Science and Business Media: Dordrecht, The Netherlands, 2010; pp. 1-28.

14. Yannopoulos, S.; Antoniou, G.; Kaiafa-Saropoulou, M.; Angelakis, A.N. Historical development of rainwater harvesting and use in Hellas: A preliminary review. Water Sci. Technol. Water Supply 2017, 17, 1022-1034. [CrossRef]

15. Robinson, D. Excavations at Olynthus, Part VIII, The Hellenic House, a study of the houses found at Olynthus with a detailed account of those excavated in 1931-1934; Oxford University Press: London, UK, 1938.

16. Hodge, T. Roman Aqueducts and Water Supply; Duckworth \& Co.: London, UK, 1992; p. 504.

17. Leggett, D.J.; Brown, R.; Brewer, D.; Stanfield, G.; Holliday, E. Rainwater and Greywater Use in Buildings: Best Practice Guidance; CIRIA Report C539; CIRIA: London, UK, 2001; p. 134.

18. Reddy, Y.A. Water Harvesting: Limitations in Implementation. In Proceedings of the 22nd National Convention of Environmental Engineers and National Seminar on Rainwater Harvesting and Water Management, Nagpur, India, 11-12 November 2006; Institution of Engineers: Nagpur, India, 2006; pp. 70-77.

19. Prinz, D.; Malik, A.H. Runoff Farming; WCA InfoNET: Rome, Italy, 2002; p. 39.

20. Boers, T.M. Rainwater Harvesting in Arid and Semi-Arid Zones; Publication No. 55; International Institute for Land Reclamation and Improvement (ILRI): Wageningen, The Netherlands, 1994; p. 127.

21. FAO (Food and Agriculture Organization). Role of forestry in combating desertification. In Proceedings of the FAO Expert Consultation on the Role of Forestry in Combating Desertification, Saltillo, Mexico, 24-28 June 1985; FAO Conservation Guide No. 21. FAO: Rome, Italy, 1989; p. 333.

22. Pacey, A.; Cullis, A. Rainwater Harvesting: The Collection of Rainfall and Runoff in Rural Areas; Intermediate Technology Publications: London, UK, 1986; p. 216.

23. Lauritzen, C.W. Ground Covers for Collecting Precipitation. Farm Home Sci. Utah Sci. 1960, 21, 66-67, 87. Available online: http://digitalcommons.usu.edu/utscience/vol21/iss3/1 (accessed on 20 January 2018).

24. Frasier, G.W.; Myers, L.E. Handbook of Water Harvesting; Agriculture Handbook No. 600; U.S. Department of Agriculture: Washington, DC, USA, 1983; p. 45.

25. Critchley, W.; Siegert, W.K. Water Harvesting: A Manual for the Design and Construction of Water Harvesting Schemes for Plant Production; AGL/MICS/17/91; FAO: Rome, Italy, 1991; p. 154.

26. USEPA (U.S. Environmental Protection Agency). Rainwater Harvesting: Conservation, Credit, Codes, and Cost Literature Review and Case Studies; U.S. EPA, EPA-841-R-13-002; USEPA: Washington, DC, USA, 2013; p. 36.

27. Koenig, K.W.; Sperfeld, D. Rainwater Harvesting-A Global Issue Matures; Fachvereinigung Betriebs- und Regenwassernutzung e.V; Association for Rainwater Harvesting and Water Utilisation: Darmstadt, Germany, 2006.

28. Haut, B.; Zheng, X.-Y.; Mays, L.; Han, M.; Passchier, C.; Angelakis, A.N. Evolution of rainwater harvesting and heritage in urban areas through the millennia: A sustainable technology for increasing water availability. In Water and Heritage: Material, Conceptual, and Spiritual Connections; Willems, W.J.H., van Schaik, H.P.J., Eds.; Sidestone Press: Leiden, The Netherlands, 2015; pp. 37-56. 
29. Geddes, H.J. Water Harvesting. In Proceedings of the National Symposium of Water Resources, Use and Management, Canberra, Australia, 9-13 September 1963; Australian Academy of Sciences: Melbourne, Australia; University Press: Melbourne, Australia, 1964.

30. Currier, W.F. Water Harvesting by Trick Tanks, Rain Traps and Guzzlers. In Proceedings of the Water-Animal Relations Symposium, Twin Falls, ID, USA, 1-8 June 1973; Mayland, H.F., Ed.; USDA-ARS Snake River Conservation Research Center: Kimberly, ID, USA, 1973.

31. Geddes, H.J. Achievements in Water Harvesting Technology in Australia. In Proceedings of the International Workshop on Farming Systems, 18-21 November 1974; ICRISAT: Begumpet, India, 1974; pp. 165-176.

32. Boers, T.M.; Ben-Asher, J. A review of rainwater harvesting. Agric. Water Manag. 1982, 5, 145-158. [CrossRef]

33. Matlock, W.G.; Dutt, G.R. A Primer on Water Harvesting and Runoff Farming, 2nd ed.; Agricultural Engineering Department, College of Agriculture, University of Arizona: Tucson, Arizona, USA, 1986; p. 126.

34. MoALD. Runoff Harvesting for Crop, Range and Tree Production in the BPSAAP-Area; Baringo Pilot Semi-Arid Area Project (BPSAAP) Interim Report Baringo Pilot Semi-Arid Area Project; Ministry of Agriculture and Livestock Development, Government of Kenya: Nairobi, Kenya, 1984.

35. Critchley, W.R.S.; Finkel, M.M. Some Lessons from Water Harvesting in Sub-Saharan Africa; Report from a Worlshop held in Baringo, Kenya, 13-17 October 1986; The World Bank: Washington, DC, USA, 1987; p. 58.

36. Bruins, H.J.; Evenari, M.; Nessler, U. Rainwater-harvesting agriculture for food production in arid zones: The challenge of the African famine. Appl. Geogr. 1986, 6, 13-32. [CrossRef]

37. Das, D.C. Surface water development in arid zones. In Sand Dune Stabilisation, Shelterbelts and Afforestation in Dry Zones; FAO, Conservation Guide No. 10; FAO: Rome, Italy, 1985; pp. 203-219.

38. Evenari, M.; Shanan, L.; Tadmor, N. The Negev: The Challenge of a Desert; Harvard University Press: Cambridge, MA, USA, 1971; p. 437.

39. Huibers, F.P. Rainfed Agriculture in a Semi-Arid Tropical Climate: Aspects of Land and Water Management for Red Soils in India. Ph.D. Thesis, Agricultural University of Wageningen, Wageningen, The Netherlands, 1985.

40. Kutsch, H. Currently used techniques in rainfed water concentrating culture: The example of the Anti-Atlas. Appl. Geogr. Dev. 1983, 21, 108-117.

41. Llopart-Mascaró, A.; Ruiz, R.; Martínez, M.; Malgrat, P.; Rusiñol, M.; Gil, A.; Suárez, J.; Puertas, J.; Rio, H.; Paraira, M.; et al. Analysis of Rainwater Quality: Towards Sustainable Rainwater Management in Urban Environments-Sostaqua Project. In Proceedings of the 7th International Conference on Sustainable Techniques and Strategies in Urban Water Management (NOVATECH 2010), Lyon, France, 27 June-1 July 2010.

42. Lade, O.; Oloke, D. Modelling Rainwater System Harvesting in Ibadan, Nigeria: Application to a Residential Apartment. Am. J. Civ. Eng. Architect. 2015, 3, 86-100.

43. Kisakye, V.; Van der Bruggen, B. Effects of climate change on water savings and water security from rainwater harvesting systems. Resour. Conserv. Recycl. 2018, 138, 49-63. [CrossRef]

44. Ringler, C.; Rosegrant, M.W.; Paisner, M.S. Irrigation and Water Resources in Latin America and the Caribbean: Challenges and Strategies; EPTD Discussion Paper No. 64; International Food Policy Research Institute (IFPRI): Washington, DC, USA, 2000; p. 92.

45. Coombes, P. Guidance on the Use of Rainwater Harvesting Systems for Rain Harvesting. Available online: http://rainharvesting.com.au/wp-content/uploads/media_Research_Assoc_Prof_Peter_Coomber_ Expert_Report_for_Guidance_of_Rainwater_Harvesting_Systems_2006.pdf (accessed on 20 January 2017).

46. CMHC (Canada Mortgage and Housing Corporation). Collecting and Using Rainwater at Home: A Guide for Homeowners; CMHC: Ottawa, ON, Canada, 2013; p. 61.

47. Lo, A.G.; Gould, J. Rainwater Harvesting: Global Overview. In Rainwater Harvesting for Agriculture and Water Supply; Zhu, Q., Gould, J., Li, Y.-H., Ma, C.-X., Eds.; Springer: Singapore, 2015; pp. 213-233.

48. E.A. (Environmental Agency). Harvesting Rainwater for Domestic Uses: An Information Guide; Environment Agency: Bristol, UK, 2010; p. 30.

49. TRCA (Toronto and Region Conservation Authority). Performance Evaluation of Rainwater Harvesting Systems; Final Report 2010 (revised June 2011); Sustainable Technologies Evaluation Program (STEP): Toronto, ON, Canada, 2010.

50. Fuentes-Galván, M.L.; Ortiz Medel, J.; Arias Hernández, L.A. Roof Rainwater Harvesting in Central Mexico: Uses, Benefits, and Factors of Adoption. Water 2018, 10, 116. [CrossRef]

51. Da Costa Pacheco, P.R.; Dumit Gómez, Y.; Ferreira de Oliveira, I.; Girard Teixeira, L.C. A view of the legislative scenario for rainwater harvesting in Brazil. J. Clean. Prod. 2017, 141, 290-294. [CrossRef] 
52. UN-HABITAT. Rainwater Harvesting and Utilisation; Blue Drop Series, Book 2: Beneficiaries \& Capacity Builders; UN-HABITAT: Mtwapa, Kenya, 2005; p. 77.

53. Liu, L.-S.; Liu, L.-G.; Wu, L.-X.; Wu, J.L.-P.; Huo, W.J. Problems and countermeasures on the safety of rainwater harvesting for drinking in China. MATEC Web Conf. 2016, 68, 14006. [CrossRef]

54. Koenig, K. The Rainwater Technology Handbook, 1st ed.; Wilo-Brain: Dortmund, Germany, 2001; p. 143.

55. Furumai, H.; Kim, J.; Imbe, M.; Okui, H. Recent application of rainwater storage and harvesting in Japan. In Proceedings of the 3rd IWA International Rainwater Harvesting and Management Workshop as a part of IWA-Viena World Water Congress \& Exhibition, Vienna, Austria, 11 September 2008; p. 7.

56. JFS (Japan for Sustainability). Let's Use Rainwater! Recent Trends in Rainwater Use in Japan. Available online: http://www.japanfs.org/en/news/archives/news_id035023.html (accessed on 20 January 2017).

57. JFS (Japan for Sustainability). Cabinet of Japan Decide to Make Full Use of Rainwater in Newly Constructed Buildings. Available online: http://www.japanfs.org/en/news/archives/news_id035257.html (accessed on 20 January 2017).

58. Campisano, A.; Butler, D.; Ward, S.; Burns, M.J.; Friedler, E.; DeBusk, K.; Fisher-Jeffes, L.N.; Ghisi, E.; Rahman, A.; Furumai, H.; et al. Urban rainwater harvesting systems: Research, implementation and future perspectives. Water Res. 2017, 115, 195-209. [CrossRef]

59. Lo, K.F.A. Multi-Faceted Use of Rainwater Harvesting to Combat Water Problems. In Proceedings of the 11th IRCS Conference Towards a New Green Revolution and Sustainable Development Through an Efficient Use of Rainwater, Texcoco, Mexico, 25-29 August 2003.

60. De Graaf, R.E. Innovations in Urban Water Management to Reduce the Vulnerability of Cities. Ph.D. Thesis, Delft University of Technology, Delft, The Netherlands, 2009.

61. Li, X.-Y. Rainwater harvesting for agricultural production in the semiarid loess region of China. J. Food Agric. Environ. 2003, 1, 282-285.

62. MARWAS, A.G. Water \& Water Treatment in India. Market Opportunities for Swiss Companies; OSEC: Zurich, Switzerland, 2010; p. 28.

63. Lee, K.E.; Mokhtar, M.; Mohd-Hanafiah, M.; Halim, A.A.; Badusah, J. Rainwater harvesting as an alternative water resource in Malaysia: Potential, policies and development. J. Clean. Prod. 2016, 126, 218-222. [CrossRef]

64. Mohd Shawahid, H.O.; Suhaimi, A.R.; Rasyikah, M.K.; Jamaluddin, S.A.; Huang, Y.F.; Farah, M.S. Policies and incentives for rainwater harvesting in Malaysia. In Proceedings of the Colloquium on Rainwater Utilization, Putrajaya, Malaysia, 19-20 April 2007; Ministry of Natural Resources and National Hydraulic Research Institute of Malaysia (NAHRIM): Putrajaya, Malaysia, 2007; pp. 1-15.

65. Liaw, C.-H.; Chiang, Y.-C. Framework for Assessing the Rainwater Harvesting Potential of Residential Buildings at a National Level as an Alternative Water Resource for Domestic Water Supply in Taiwan. Water 2014, 6, 3224-3246. [CrossRef]

66. Herrmann, T.; Schmida, U. Rainwater Utilisation in Germany: Efficiency, dimensioning, hydraulic and environmental aspects. Urban Water 1999, 1, 307-316. [CrossRef]

67. Nolde, E. Possibilities of rainwater utilisation in densely populated areas including precipitation runoffs from traffic surfaces. Desalination 2007, 215, 1-11. [CrossRef]

68. Partzsch, L. Smart regulation for water innovation-the case of decentralized rainwater technology. J. Clean. Prod. 2009, 17, 985-991. [CrossRef]

69. Schuetze, T. Rainwater harvesting and management-Policy and regulations in Germany. Water Sci. Technol. Water Supply 2013, 13, 376-385. [CrossRef]

70. Ward, S. Rainwater Harvesting in the UK - Current Practice and Future Trends. Available online: http: //www.harvesth2o.com/rainwater_harvesting_UK.shtml (accessed on 15 January 2018).

71. UKRHA (United Kingdom Rainwater Harvesting Association). Enhanced Capital Allowance Scheme as it Applies to Rainwater Harvesting Systems; Industry Fact Sheet No 3; UKRHA: Nottinghamshire, UK, 2006.

72. Gerolin, A.; Le Nouveau, N.; de Gouvello, B. Rainwater harvesting for stormwater management: Example-based typology and current approaches for evaluation to question French practices. In Proceedings of the 8th International Conference, Novatech, Lyon, France, 23-27 June 2013; p. 10.

73. Vialle, C.; Busset, G.; Tanfin, L.; Montrejaud-Vignoles, M.; Huau, M.-C.; Sablayrolles, C. Environmental analysis of a domestic rainwater harvesting system: A case study in France. Resour. Conserv. Recycl. 2015, 102, 178-184. [CrossRef] 
74. Belmeziti, A.; Coutard, O.; de Gouvello, B. A New Methodology for Evaluating Potential for Potable Water Savings (PPWS) by Using Rainwater Harvesting at the Urban Level: The Case of the Municipality of Colombes (Paris Region). Water 2013, 5, 312-326. [CrossRef]

75. Campling, P.; De Nocker, L.; Schiettecatte, W.; Iacovides, A.I.; Dworak, T.; Arenas, M.A.; Pozo, C.C.; Le Mat, O.; Mattheiß, V.; Kervarec, F. Assessment of the Risks and Impacts of Four Alternative Water Supply Options; European Commission-DG Environment: Brussels, Belgium, 2008.

76. Silva, C.M.; Sousa, V.; Carvalho, N.V. Evaluation of rainwater harvesting in Portugal: Application to single-family residences. Resour. Conserv. Recycl. 2015, 94, 21-34. [CrossRef]

77. Reitano, R. Water Harvesting and Water Collection Systems in Mediterranean Area. The Case of Malta. Procedia Eng. 2011, 21, 81-88. [CrossRef]

(C) 2019 by the authors. Licensee MDPI, Basel, Switzerland. This article is an open access article distributed under the terms and conditions of the Creative Commons Attribution (CC BY) license (http://creativecommons.org/licenses/by/4.0/). 